\title{
THE FIELD OF GOVERNMENTAL PRICE CONTROL
}

\section{HENRY ROTTSCHAEFER}

Governmental price regulation was practised at an early stage in English legal history, and constituted an important element in the economic life of the Middle Ages. ${ }^{1}$ It was an integral part of a social order strongly influenced by ethical conceptions of a just price capable of the same kind of objective determination as any other ethical standard. ${ }^{2}$ It was the natural expression of the prevailing idea that it was distinctly the business of the state to regulate the conduct of trade, which itself was a phase of the mediaeval respect for, and reliance upon, authority. ${ }^{3}$ The ideas of that period were gradually supplanted by those of an expanding individualism, which culminated in the philosophic assumption of the classical economists that social welfare was an inevitable by-product of competitive individualism.* This shift in ideas had its counterpart in changing governmental practices that allowed business and trade an increasingly larger field for self-determination. The Spencerian theory of the function of government was in large measure realized during a considerable portion of the nineteenth century, not only in England but also in the United States where it found congenial soil in the conditions of an undeveloped and pioneer community. The ideas of the earlier period never completely disappeared; and, during the very period when the theory of laissez faire was in process of definite formulation, legislative price fixing was being resorted to in the American colonies ${ }^{\sigma}$ and the field of price regulation was being judicially extended in England. ${ }^{6}$ The most conspicuous case of survival was that of the common carrier. The essential difference between the earlier and later periods was one of emphasis. In the former, governmental control was an integral part of an accepted social régime; in the latter, it had acquired the character of an exceptional policy. Changing conditions resulted in a considerable revival of price control that began in this country during

1 Freund, Police Power (1904) 382; Cheadle, Government Control of Business (1920) 20 CoL. L. REv. 438, 550. Note AND Comment (1920) 19 Mrch. L. REv. 74; Gilmore, Governmental Regulation of Prices (1905) 17 Grean BAG, 627.

22 Holdsworth, A History of English Law (3d ed. 1923) 468.

34 Ibid. (1924) 386.

4 See generally, Adam Smith, Wealth of Nations; Ricardo, Principles of Political Economy and Taxation, passim.

- Freund, op. ait. supra note 1, at 384; Notes (1920) 33 HARv. L. REv. 838.

${ }^{6}$ Allnutt v. Inglis (1810, K. B.) 12 East, 527. 
the latter third of the nineteenth century, and has proceeded at an accelerated pace during the last two decades. It is the constitutional problem involved in the legislative definition of the field of economic activity liable to this type of control that constitutes the subject matter of the present discussion. The principles governing its judicial extension will not be considered:

There are many forms of governmental regulation which indirectly affect prices; and certain taxes do so directly. The term "price control" will, however, be used in this discussion to indicate those governmental regulations which not only operate directly upon prices but are also adopted for the very purpose of producing that effect. The subsequent discussion of the principles involved will be facilitated by a survey of the decisions on its validity. Its first important extension was to the business of grain elevation at commercial centers. This was soon followed by applying the principle to the same business in a predominantly agricultural state where the conditions under which it was conducted were radically different. The constitutionality of these measures was sustained in both instances. ${ }^{8}$ At about the same time the legislative power to prescribe railrosd rates was definitely established. ${ }^{9}$ The extreme legislative antivity in this respect that characterized the Granger movement abated somewhat after these decisions, although not until stoelyards had been subjected to price control.10 Then followed a brief period of comparative quiescence, succeeded in turn by one of increased legislative activity commencing near the close of the first decade of the twentieth century and reaching its maximum during and just after the war. The result was a considerable expansion of the field of price control, and the definite exclusion therefrom of certain types of economic activity. Its constitutionality has been sustained, either by the United States Supreme Court or by the highest court of various states, as applied to the businesses of insurance, ${ }^{11}$ carrying oil by pipe lines, ${ }^{12}$ furnishing

7 For discussion of these problems see Burdich, The Origin of the Pcenliar Duties of Public Service Companies (1911) 11 CoL. L. Rev. 514, 616, 743; Wyman, The Law of the Public Callings as a Solution of the Trust Problen (1904) 17 HARv. L. REv. 156, 217; Adler, Business Jurisprudcitec (1914) as HARV. L. REv. 135.

8 IIunn v. Illinois (1877) 94 U. S. 113; Brass v. North Dalota (1891) 153 U. S. 391, 14 Sup. Ct. 857. For a discussion of the MIunz ease, see Finkelnburg, The Power of the State to Regulate Prices and Cherges (1898) 32 AMr. L. REv. 501.

${ }^{9}$ Peik v. Chicago \& N. W. Ry. (1877) 94 U. S. 104.

${ }^{10}$ Cotting v. Kansas City Stock Yards Co. (1901) 183 U. S. 79, 22 Sup. Ct. 30.

${ }^{11}$ German Alliance Insurance Co. v. Lewis (1914) 233 U. S. 289, 34 Sup. Ct. 612.

12 The Pipe Line Cases (1914) 234 U. S. 548, 34 Sup. Ct. 950. 
electricity not directly to the public but to a utility that serves the public, ${ }^{13}$ distributing ice, ${ }^{14}$ cold storage warehousing, ${ }^{10}$ reselling theatre tickets, ${ }^{10}$ the selling of coal ${ }^{17}$ and the renting of dwellings and other buildings. ${ }^{18}$ The power to fix prices for furnishing steam-heat went unchallenged in one case; ${ }^{10}$ and in another, in which the Federal Supreme Court invalidated a rate order because the statutes made no adequate provision for judicial review, the power to regulate the prices of laundry services seems to have been tacitly assumed. ${ }^{20}$ The power of the federal government to fix coal prices as a war measure has been up. held ;21 and, although the price-regulative provisions of the Lever Act:2 were held invalid because of the indefiniteness of the established price standard, ${ }^{23}$ the federal power to control the prices of necessaries therein provided for was sustained by various lower federal courts as to several kinds of necessaries."24 The Supreme Court did not pass upon the validity of the Lever Act in this respect. No more than a reference is required to the governmental power to control prices in the field of the recognized public utilities such as the railroads," telephone and tele-

${ }^{13}$ Southern Oklahoma Power Co. v. Corporation Commission (1923) 06 Okla. 53, 220 Pac. 370.

14 Olelahoma Lt. \& Power Co. v. Corporation Commission (1923) 96 Okla. 19, 220 Pac. 54.

15 Public Utility Commission v. The Monarch Refrigerating Co. (1015) 267 Ill. 528, 108 N. E. 716.

${ }^{16}$ People v. Weller (1924) 237 N. Y. 316, 143 N. E. 205; aff'd in Weller v. People (1925) 268 U. S. 319, 45 Sup. Ct. 556 (but without considering power to fix prices); In re Opinion of the Justices (1924) 247 Mass. 580, 143 N. E. 808. See (1924) 33 YAle LaW Journal, 434 ; Notes AND Comment (1924) 9 CoRn. L. Quart. 321; Notes (1924) 37 HaRv. L. Rev. 1125.

15 American Coal Mining Co. v. Special Coal and Food Comm. of Ind. (1920, D. C. Ind.) 268 Fed. 563.

${ }^{18}$ Block v. Hirsh (1921) 256 U. S. 135, 41 Sup. Ct. 458; Brown Holding Co. v. Feldman (1921) 256 U. S. 170, 41 Sup. Ct. 465 . See Boyd, Ront Regulation under the Police Power (1921) 19 Mrch. L. REv. 599; Wickersham, The Police Power and the New York Emergency Rent Laws (1921) 69 U. PA. L. REv. 301; Smith, Thd Granger Cases (1924) 10 A. B. A. Jour. 343. ${ }^{19}$ State ex rel. Case v. Public Service Comm. (1923) 298 Mo. 303, 249

S. W. 955.

${ }^{20}$ Oklahoma Operating Co. v. Love (1920) 252 U. S. 331, 40 Sup. Ct. 338. 21 United States v. Pennsylvania Central Coal Co. (1918, W. D. Pa.) 256 Fed. 703.

22 Act of Oct. 22, 1919 (41 Stat. at L. 297, 298).

23 United States v. Cohen Grocery Co. (1921) 255 U. S. 81, 41 Sup. Ct. 298.

${ }^{24}$ United States v. Spokane Dry Goods Co. (1920, E. D. Wash.) 264 Fed. 209; United States v. Cohen Grocer Co. (1920, E. D. Mo.) 264 Fed. 218; C. A. Weed \& Co. v. Lockwood (1920, W. D. N. Y.) 264 Fed. 453; Unitod States" v. Rosenblum (1920, W. D. Pa.) 264 Fed. 578; United States v. Oglesby Grocery Co. (1920, N. D. Ga.) 264 Fed. 691 . See Notes (1920) 60 U. PA. L. REv. 56.

${ }^{25}$ Peik v. Chicago \& N.W. Ry., supra note 9. 


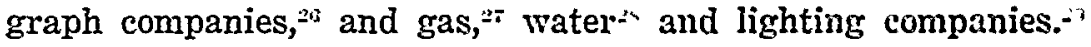

The movement, however, received several checks. The state's power to fix rates for furnishing surety bonds and indemnity contracts was denied in a case decided before the Gcrman Alliance Insurance Co. case. ${ }^{\text {an }}$ Efforts at limiting the commissions chargeable by employment agencies have been held invalid in several cases, ${ }^{31}$ while an attempt to deny them the right to charge any commissions whatever met a like fate in the Federal Supreme Court. ${ }^{32}$ The state cannot limit the profits of retail dealers of school text books, although it can do so in the case of retail dealers selected by public school authorities to act as their agents in the sale of text books purchased by such authorities. ${ }^{3}$ An effort to empower a state commission to fix the prices of all commodities has been held unconstitutional..$^{\text {sis }}$ It is, however, in the field of fixing the prices of labor and other forms of personal service that the most definite and serious check has been received. This power has been denied even in the case of the wages to be paid by public contractors. ${ }^{35}$ Nor can public authorities fix the compensation to be paid by the owners of a theatre to a fire guard required to be maintained there. ${ }^{35}$ Congress has no power to prescribe minimum wages for women ;" but the existence of an emergency in the form of a threatened general railroad strike confers upon it the power to fix the wages of railroad employees engaged in interstate commerce for at least a limited period. Whatever doubts may have existed after the Adlins case as to

26 Westem Union Tel. Co. w. Myatt (1899, C. C. Kan.) 98 Fed. 335.

2 Cleveland Gaslight \& Coke Co. v. Clcreland (1891, C. C. N. D. Ohio) 71 Fed. 610.

${ }^{28}$ Spring Valley Water Woils w. Schottler (1884) 110 U. S. 347, 4 Sup. Ct. 48. 13.

${ }^{29}$ Southern Olilahoma Pouer Co. v. Corporation Comminsion, supra note

${ }^{30}$ American Surety Co. v. Shallenbergcr (1910, C. C. Neb.) 183 Fed. 636

${ }^{31}$ Ess parte Diekey (1904) 144 Calif. 234, 77 Pae. 924; Wilson $\tilde{z}^{2}$. Cily and County of Denver (1919) 65 Colo. 484, 178 Pae. 17; Comment 0N CAsEs (1923) 12 CALIF. L. REv. 511.

32 Adams v. Tanner (1917) 244 U. S. 590, 37 Sup. Ct. 662.

3s McMillan Co. v. Johnson (1920, E. D. Mich.) 269 Fed. 28.

${ }^{34}$ A. II. Holter Hardvare Co. v. Boyle (1920, D. C. MIont.) 293 Fed. 132. See Notes (1920) 33 HARv. L. REv. 838.

35 Street v. Vamey Electrical Supply Co. (1903) 160 Ind. 898, 60 N. E. 895; People ex rel. Rodgers v. Coler (1901) 160 N. Y. 1, 59 N. E. 716; contra: Malette v. Spoliane (1913) 77 Wash. 205, 137 Pac. 496.

38 O'Neil v. Providence Amusement Co. (1920) 42 R. I. 479, 108 Atl. 887. ${ }^{3 \pi}$ Adkizs v. Children's Hospital (1923) 261 U. S. 525, 43 Sup. Ct. 394.

38 Wilson v. New (1917) 213 U. S. 332, 37 Sup. Ct. 298. See Powell, Due Process and the Adamson Lav" (1917) 17 CoL. L. Rev. 114; Powell, The Supreme Coust and the Adamson Law (1917) 65 U. PA. L. REv. 607. The former article was written prior to the decision. 
the constitutionality of state minimum wage laws for women ${ }^{30}$ have been resolved by the recent holding which invalidates them. ${ }^{40}$ Nor can a state regulate wages generally if that regulation is an integral part of a general plan of compulsory arbitration of industrial disputes. ${ }^{41}$ The Supreme Court in the $A d$ leins case expressly declined to consider the validity of Congressional minimum wage legislation as applied to minors ${ }^{42}$ and at least one state court, influenced thereby, has sustained a state minimum wage law in such case. ${ }^{43}$ Much of the reasoning in the Adlins case would condemn such laws even as applied to minors. ${ }^{44}$ There is, however, one field of personal services in which price fixing has been generally recognized as valid, namely, that of attorney's services of certain kinds. The power of Congress to limit attorney's fees for prosecuting claims against the United States to a stated percentage of the amount recovered has been sustained on various theories that will be hereinafter more fully considered. ${ }^{45}$ State statutes have similarly been upheld that limited such fees for services rendered in presenting claims arising under workmen's compensation acts to sums fixed by the boards charged with the administration of such statutes. ${ }^{41}$

Most of the instances discussed in the two preceding paragraphs involved the fixing of specific prices either by the legislature or a commission; some dealt with legislative definitions of a price standard the exact meaning of which in particular cases was a matter for judicial determination, in somewhat the same manner as the duty of common carriers to carry for a "reason" able" rate at the common law. The common element in all of them was the complete absence of the regulated person's will and initiative as a factor in fixing the price or standard. This rep-

${ }^{39}$ See Stetler v. O'Hara (1917) 243 U. S. 629, 37 Sup. Ct. 475 . For collection of authorities prior to decision in the Adlins case see Powell, Judiciality of Minimum-Wage Legislation (1924) 37 HARv. L. REv. 545, footnotes 3 to 7 , inclusive.

${ }^{40}$ John W. Murphy v. A. Sardell (Oct. 19, 1925) U. S. Sup. Ct., Oct. Term, 1925, No. 18 (Memorandum).

41 Wolff Pacling Co. v. Court of Industrial Relations (1923) 262 U. S. 522, 43 Sup. Ct. 630; Comments (1923) 33 Yale LaW Jounnal, 196; Note AND Comment (1923) 22 MICH. L. REv. 135. For a discussion of the history and functioning of the Kansas Court of Industrial Relations, see Rabinowitz, The Kansas Industrial Court Act (1923) 12 CALIF. L. Rev. 1.

42 Adlins v. Ehildren's Hospital, supra note 37, at 554, 43 Sup. Ct. at 400.

${ }^{43}$ Stevenson v. St. Clair (1925, Minn.) 201 N. W. 629.

44 This is particularly true in so far as the opinion in the Adlins case stresses the moral requirement that wages must bear some relation to tho value of the service.

${ }_{45}$ Frisbie v. United States (1895) 157 U. S. 160, 15 Sup. Ct. 586; Ball v. Halsell (1896) 161 U. S. 72, 16 Sup. Ct. 554; Calhoun v. Massie (1920) 253 U. S. 170, 40 Sup. Ct. 474. See Notes (1916) 29 HARv. L. Rev. 328.

${ }^{46}$ Dysart v. Yeiser (1923) 110 Neb. 65, 192 N. W. 953; Gritta's Caso (1922) 241 Mass. 525, 135 N. E. 874. 
resents the extreme of price control. There is a milder form that has been quite extensively employed, in which the standard for prices in one locality is stated in terms of prices for the same commodity voluntarily maintained by the seller or purchaser in another locality. Statutes of this kind have invariably aimed at practices frequently resorted to by those bent on monopoly. It is this fact which obscured their essential character as a type of governmental price control. The imposition of such limitation upon the seller's freedom of action has been upheld in the case of sellers of petroleum and its products, $;:$ and of commodities in general. ${ }^{\text {s }}$ The validity of similar restrictions upon purchasers of farm products in agricultural states has been sustained in several states..$^{19}$

The most cursory examination of the decisions sustaining and denying the validity of government price control shows the futility of attempting to discover the underlying prineiples apart from an analysis of the reasoning of the courts. The cases may for this purpose be conveniently divided into the following groups: (1) those involving price control of the product of a business or industry, whether a commodity or a service, in which the producer's will constitutes no factor in determining the price or price standard; (2) those involving a similar fixing of wages or other form of compensation for personal services; and (3) those involving the establishment of a price standard in terms of other prices voluntarily maintained by those subjeet to the regulation. The first of these is easily the most important group; the last the least significant. They will be considered in the order of their statement.

The case of MIunn v. Illinois ${ }^{50}$ was the first important instance in which the Federal Supreme Court formulated the constitutional problems raised by government price control. Our present concern is solely with its validity under the "due process" clause. The "commerce" and "contract" clauses of the Federal Constitution have sometimes been invoked against price control, ${ }^{, 2}$ but the "due process" clauses of the Fifth and Fourteenth Amendments have been the principal reliance of those who have opposed it. The reasoning of the MItmin case is, in brief, that the power to regulate prices had in the past been exercised by the government of the nation from which our legal conceptions were de-

47 State es rel. Young v. Standard Oil Co. (1910) 111 Minn. 85, 120 N. W. 527. See also Central Lumber Co. v. South Daloota (1912) 220 U. S. 157, 33 Sup. Ct. 66.

48 State v. Drayton (1908) 82 Neb. 254, 117 N. W. 768.

19 Síate v. Bridgemain \& Russell Co. (1912) 117 Minn. 186, 134 N. W. 496; State v. Fairmont Creamery Co. (1912) 153 Iowa, 702, 133 N. W. 895. so Supra note 8.

51 Ibid. (commerce clause); Brown Holding Co. v. Feldman, supro note 18 (contract clause). 
rived; that that government was subject to the same kind of limitations as were imposed upon our state and federal governments by the "due process" clauses; that the legal principles justifying such regulation were discoverable in the common law because the rights protected by those constitutional provisions came from it; that the significant principle was that when property becomes affected with a public interest, it ceases to be juris privati only, and may have the price of its uses regulated; and that the fact of a virtual monopoly, which was an assumed fact in the case, was in the case of some businesses a sufficient common law basis on which to predicate that requisite characteristic. This whole argument is vitiated by the tacit assumption that the common law furnishes the measure of what our legislatures can do under our constitutions. The approach is rather that of a court extending the field of price control apart from legislation than of a court defining the constitutional limits of a legislative expansion of the field. This was probably due to the fact that the two problems had not yet been adequately differentiated. The dissenting opinion is based on the same assumption and manifests the same confusion of problems..$^{52}$ It is, of course, impossible to determine how the persistence of this erroneous approach might have affected the course of judicial decisions on the legislative power of price control. The common law is a vast reservoir in which it would have been possible to discover, if necessary, general principles of the most sweeping character to justify price fixing in a wide field. It would, however, have considerably affected the technique for establishing the validity of such efforts by overemphasizing the importance of historical factors at the expense of a rational consideration of present needs. It is, therefore, a considerable gain that the courts have long since adopted a different conception of the problem. There has been no material change in the form in which the question is stated. It has always been correctly conceived as defining the limits set to the police or some other governmental power by various constitutional prohibitions of which the "due process" clauses are the most important. There has, however, been a considerable change in the factors relied upon as determinants of the answer. The earlier cases abound with references to historical instances of price control $;^{63}$ the analogies relied upon in the later cases are decisions involving other exercises of the police power, ${ }^{54}$ and this is as true of the dissenting as of the prevailing opinions. ${ }^{55}$

${ }^{52}$ Field, J. in Munn v. Illinois, supro note 8.

${ }^{53}$ Munn v. Illinois, supra note 8. For a late case in which the historical argument was used against the present existence of the power to fix prices see A. M. Holter Hardware Co. v. Boyle, supra note 34.

${ }^{34}$ Block v. Hirsh, supra note 18.

${ }^{55}$ German Alliance Insurance Co. v. Lewis, supra note 11. 
The MIunn case made liability to price control depend on the fact that the property used in the business was affected with a public interest. The erroneous implication that it was limited to cases in which the regulated subject was the use of property has long since been eliminated. There has been substituted the conception of business affected with a public interest. ${ }^{3}$ The problem today is conceived as that of delimiting the field of business activity constitutionally subject to price control; and it is realized that the determining factors are independent of whether the business consists in supplying the public with commodities, the uses of property, or services in whose rendering the use of property is practically unimportant. The principal issue has been to determine the kind or degree of public interest that must exist in order that the business may be said to be thus affected with a public interest. The courts have grappled with this problem through an extended series of cases; but thus far their efforts not only to evolve a logical definition but even to give the conception definite and concrete content have proved futile. This will be apparent from the following comparatively recent statement:

"The circumstances which clothe a particular kind of business with a public interest, in the sense of MIunn $v$. Illinois and the other cases, must be such as to create a peculiarly close relation between the public and those engaged in it, and raise implications of an affirmative obligation on their part to be reasonable in dealing with the public." is

That the courts themselves have recognized this appears clearly from the following language in the opinion last cited:

"It is very difficult under the cases to lay down a working rule by which readily to determine when a business has become 'clothed with a public interest.' All business is subject to some kinds of public regulation, but when the public becomes so peculiarly dependent upon a particular business that one engaging therein subjects himself to a more intimate public regulation is only to be determined by the process of exclusion and inclusion and to gradual establishment of a line of distinetion." 53

The difficulties that have thus far prevented courts from achieving a satisfactory definition and description of the conception are so inherent in the problem that future efforts in that direetion are little likely to prove more successful. The only avail-

\footnotetext{
is See dissenting opinion in German Alliance Insurance Co. a. Lavis, supros note 11, at 425 et seq., 34 Sup. Ct. at 624, for statement of this view.

st See majority opinion in case last cited, at 408 ot scq., 84 Sup. Ct. at 617 et seq.

ss Wolff Packing Co. v. Court of Industrial Relations, supro note 11 at 536, 43 Sup. Ct. at 633 .

s9 Ibid., at 538, 539, 43 Sup. Ct. at 634 .
} 
able method is an inductive study to discover the facts on which the courts have predicated the requisite public interest.

The legislative fiat that the requisite public interest exists is not in itself a sufficient fact to establish such interest.00 Other facts must exist to give that judgment the character of reasonableness. The prevailing opinion in the Munn case found such fact not, as is usually stated, ${ }^{61}$ in the mere existence of a virtual monopoly, but in the existence of such monopoly in a business in which as a result thereof the producers were in a position to impose upon the public what the court calls a "common charge." or The New York court in passing upon a statute very similar to that involved in the Munn case based the existence of the requisite public interest not upon a single fact, but upon a series of facts which included the nature and extent of the business, its importance as an element in the trade and commerce of the state and nation, the relation of the business to the prosperity and welfare of the state, the fact that the business was rendered possible only by the existence of a canal built and maintained at public expense, and the existence of a virtual monopoly. ${ }^{\circ 3}$ The decision was affirmed by the Federal Supreme Court in an opinion expressly approving as sound the views of the New York court above set forth. ${ }^{64}$ The public interest that justified regulating the price of fire insurance was based as much upon its practical necessity to business activity and enterprise and the disparity in bargaining power between the insured and insurer as upon virtual monopoly. ${ }^{\circ 0}$ The Rent Cases afford further proof that the requisite interest usually arises from a group of facts rather than from a single fact. Those specifically mentioned are the existence of a public exigency, the embarrassment to the government and danger to the public health of the existing conditions, the character of housing as a necessity of life, and the necessary monopolistic character of the business. ${ }^{66}$ The existence of a practical monopoly in a necessary of life was held to justify fixing the price of ice. ${ }^{07}$ It is not even essential that the regulated article come within the class of necessaries. It has been held sufficient that it is one, such as theatre tickets, which the public desires or commonly uses, if circumstances, such as monopolistic control, result in extortionate prices therefor. ${ }^{68}$ The historical fact that places of amusement had always been considered and treated in the state as affected

60 Ibid., at 536, 43 Sup. Ct. at 633 .

61 Wyman, op. cit. supra note 7.

62 Munn v. Illinois, supra note 8 , at 132.

${ }^{63}$ People v. Budd (1889) 117 N. Y. 1, 22 N. E. 670.

a4 Budd v. New York (1892) 143 U. S. 517, 12 Sup. Ct. 468.

os German Alliance Insurance Co. v. Lewis, supra note 11.

${ }^{\circ 6}$ Block v. Hirsh, supra note 18, at 156, 41 Sup. Ct. at 459.

or Olilahoma Lt. \& Power Co. v. Corporation Commission, supra note 14.

${ }^{68}$ People $v$. Weller, supra note 16. 
with a public interest and devoted to a public use (by which apparently no more was meant than that they had always been subjected to a high degree of regulation in other respects) was one factor relied upon by the MIassachusetts court in an advisory opinion sustaining the power to limit the price for the services of a ticket scalper. ${ }^{\text {c3 }}$ The grant of special privileges is a fact on which it can be predicated. ${ }^{\circ}$ It can exist even if the business is not one in which there is the duty to serve all making reasonable request therefor, or upon which such duty could be imposed by legislation. ${ }^{71}$ The business need not be one to which the public must resort; it is sufficient if in the light of business habits current at the time the public would most probably desire to avail itself of the commodity or service furnished by the business in question. ${ }^{72}$

There have been not a few cases that have sustained price fixing for commodities and services, other than personal services, without expressly and formally invoking the principle that the business involved was affected with a public interest in its narrow and technical sense. The state's power to fix coal prices was sustained on the theory that, if price regulation is a valid method for preventing oppression and extortion in the field of technical public services, it is a valid remedy to prevent the like results in the field of private business. ${ }^{33}$ The federal power to regulate coal prices during the war was upheld as a necessary war measure, and to prevent the strong from extorting unreasonable profits through the exigencies of war. ${ }^{\text {is }}$ Although the power of Congress to regulate the prices of necessaries was in one case based on the fact that the public had an interest in them, it as a necessary war measure without relying upon that prineiple. $^{76}$ The New York court in the ticket scalping casei: expressed some doubt as to whether that were a business affected with a public interest and, therefore, urged as an independent argument in favor of its validity the power of the legislature to prevent extortion by adopting the remedy most likely to effect that result. The reasoning of all these decisions, in the final analysis, is in substance that the legislatures have the power to promote the

\footnotetext{
Q9 In re Opinion of the Jintices, supre note 16.

* 70 Wolff Packing Co. v. Court of Industrial Relations, supre note 41, at 535,43 Sup. Ct. at 633.

"1 German Alliance Insurance Co. v. Lewis, supre note 11, at 407, 34 Sup. Ct. at 616.

$72 I b i d$. at 417,34 Sup. Ct. at 620.

${ }^{3}$ American Coal Ifining Co. v. Special Coal and Food Comm. of Ind, sippa note 17.

${ }^{4}$ United States v. Penzsylzania Contral Coal Co., supra note 21.

"5 United States v. Roscnblu!m, supra note 24.

${ }^{76}$ See other cases cited in note 24 .

77 People v. Weller, supra note 16.
} 
general welfare by preventing through price control the undue capitalization by any group of its economic powers. Their signifcance does not consist in their having developed a more definite and easily applied test of liability to price control. They have been no more successful in that respect than the line of cases formulating the determining factors in terms of business affected with a public interest. Their chief importance lies in their broader approach to the problem of price control. It is their special merit that they have, in the very form of its statement, recognized the problem of price control as a species of well-known and more inclusive genus.

The cases dealing with the power to fix the price of labor and other forms of personal service are significant primarily because the conception, "affected with a public interest", has been $\Omega$ practically negligible factor in the decisions. It was referred to in but two of the principal cases, and then only incidentally. ${ }^{\text {"s }}$ The problem has generally been treated as a particular instance of determining the limits imposed on legislative action by the "due process" standard, with no attempt to give it a definitely distinct complexion through a secondary formula. The various minimum wage decisions constitute the most important cases of this type. The Supreme Court has held every such law unconstitutional except that involved in Wilson $v$. New. $^{70}$ Its decisions, therefore, serve rather to define the field through indicating factors of exclusion than of inclusion. The case last cited is the only one that gives any indication of the factors on which wage fixing can be predicated. That decision is rested on more than a single reason; but the ultimate premise on which they are all based is the power of the government to prevent existing or threatened public injury by adopting a remedy reasonably adapted to achieve that result. The logical extension of this principle would justify even compulsory arbitration of industrial disputes, and the case contains an intimation to that effect. The Court has, however, refused so to extend it in a case involving a dispute in a relatively small packing plant. ${ }^{80}$ The significance of this difference in views on the matter is that the extent of the public injury is an important factor in appraising the validity of wage fixing, and that this is closely related to the importance of the industry to the community's general economic welfare. The emphasis in Wilson $v$. $N e w$ upon the fact that railroading was a public service, and its later reference in the Wolff Packing Company case to the absence of that element, suggest the inference that public service industries possess that degree of economic importance that will justify

is Wilson v. New, supra note 38; Wolff Packing Co. v. Court of Industrial Relations, supra note 41.

is Supra note 38.

so Wolff Packing Co. v. Court of Industrial Relations, supra note 41. 
wage fixing therein. It is, however, only a suggestion, for the language in the case last referred to, that the fact that a business is a public service does not justify every form of regulation, transforms an apparently definite test of inclusion into one of extreme vagueness. That quality is even truer of the tests of exclusion developed in the Adlins case with its emphasis on the fact that the wage standard was based on the necessities of one of the parties without taking account of the moral requirement that wages should bear some reasonable relation to the value of the services performed, and its stress on the theory of freedom of contract. These describe only a vague ideal, and state only conclusions based on unexpressed premises. ${ }^{\$ 2}$ Their value as factors defining the field to which wage fixing cannot validly extend is quite negligible. The Court has practically left the problem of defining the constitutional field of wage fixing in that state of convenient vagueness which characterizes most problems of "due process" as a limit on legislative action. One might well hesitate to predict on the basis of the decisions and their reasoning the fate of minimum wages for minors, or even for adult men and women in certain industrial fields. There is no logical or practical reason for limiting wage fixing to public service industries, for: evils may arise in other fields for which it would be a reasonable remedy. It must, however, be frankly admitted that the decisions and reasoning afford little ground for optimism to those who would use it to create what they believe to be a desirable social order.

The reasoning of the cases sustaining the fixing of attorney's fees afford the clearest proof that price fixing is not dependent on the existence of the facts denoted by the technical conception "affected with a public interest." The power of Congress to limit such fees has been upheld by involing its power to determine the circumstances under which applications for pensions could be prosecuted, ${ }^{82}$ and to impose conditions in consenting to suits against the United States. ${ }^{\$ 3}$ These narrow technical bases are scarcely noticed in a later case which rests the power primarily upon the purpose and tendency of such legislation to prevent extortion and improvident bargains and the stirring up of unjust claims. ${ }^{54}$ It is this danger of oppression which state courts have stressed in sustaining the fixing of attorney's fees in cases arising under their workmen's compensation acts. ${ }^{25}$ The Nebraslia

\footnotetext{
81 See for discussion of this opinion Powell, op. cit. supro note 38; Comminents (1923) 32 Yale Law Journat, 829; Note and Commenst (1923) 21 Mich. I. Rev. 906; ComMint on CAses (1923) 11 CarfF. L. Rev. 353; Notes (1924) 58 AMr. L. REr. 581.

82 Frisbie v. United States, supra note 45.

${ }^{83}$ Ball v. Halsell, supra note 45.

${ }^{84}$ Calhoun v. Massie, supra note 45.

85 Gritta's Case, supra note 46.
} 
court further emphasized the public interest in preventing the depletion of an award by improvident and unreasonable contracts for legal services, and the reasonable relation of the fee-fixing provisions to the general policy of such acts. ${ }^{86}$ The case was affirmed by the Federal Supreme Court in an opinion the language of which amounts to an approval of the state courts' reasoning, although the technical factor of the attorney's position is secondarily relied upon. ${ }^{87}$ The most significant fact that emerges from the analysis of this line of cases is the shift in the basis upon which legislation of this character has been sustained. The earlier decisions rested their validity on rather narrow and highly technical grounds; the later cases, while not entirely excluding them, rely almost wholly upon factors that take account of the realities of the problem which such legislation is intended to meet. They show clearly that price fixing is valid when the system of prices determined by individual bargaining exposes even a limited social group to the dangers of oppression and extortion, and that this is even truer where that system produces consequences injurious to the social group as a whole. It is the existence of these facts that constitutes the decisive factor. Nothing in their reasoning suggests limiting the principle to cases in which those facts are due to particular causes such as virtual monopoly. Nothing in these decisions expressly restricts their scope to services reasonably necessary in the light of current standards of living; but the services actually involved can fairly be so described. It is reasonably certain that the principles will not be applied to the services of a valet. The technical argument based on the attorney's special position affords no basis for limiting the doctrine to attorney's fees; and the same is true of the other technical bases as restrictive factors. The ultimate scope of the principle will have to be deduced from the broad general reasoning urged in its support.

The establishment of a price standard in terms of other prices voluntarily maintained by those subject to the regulation has not usually been considered in discussing the field of price control. It represents, however, a true case thereof, in that it compels the seller or buyer, in fixing prices in a particular market, to take account of a factor which he would usually wish to disregard, especially in the cases at which such legislation is aimed. The decisions sustaining it have invariably done so because it constituted a reasonable method for preserving the freedom of markets by forbidding practices frequently employed to eliminate competition..$^{88}$ The reasoning follows the conventional lines for establishing the validity of an exercise of the police power. The

${ }^{86}$ Dysart v. Yeiser, supra. note 46.

8т Yeiser v. Dysart (1925, U. S.) 45 Sup. Ct. 399.

88 See cases cited in notes 47,48 , and 49 . 
preservation of competition is assumed to be a socially desirable end; the establishment of such price standards a reasonable means for its promotion. The conception, "affected with a public interest", constituted no factor in it.

The discussion thus far has been devoted to a survey of the decisions and the specification of the important factors that have contributed to shaping the law, in so far as they are stated in the opinions. It is a fair question whether they admit of any practically useful generalization which will summarize not only the situations in which price control is valid, but also those in which it is invalid. MIost of the attempted generalizations have been made with sole reference to businesses affected with a public interest. The frequent emphasis on the fact of virtual monopoly has led one writer to make that the sole factor in defining what businesses were affected with a public interest in so far as that was independent of the grant of special privileges or firanehises. .3 It was advanced as the sole determinant of the validity of price control in that field not only in the sense that its existence justified that type of regulation, but that its absence interposed a bar to its constitutionality. The broadest possible conclusion warranted by the cases was that virtual monopoly justified price control; to draw the further inference that there were no other circumstances justifying it involved a patent non-sequitu $i$, and ignored $B i a s s v$. North Dakota. ${ }^{30}$ The theory also overlooked the reference to other factors in most of the cases. The character of the commodity or service as a necessary is stressed almost as much and as often as the element of virtual monopoly. There are no rules for certainly determining the decisive factor on which a legal conclusion depends when the cases from which it is derived more frequently than not refer to a group of factors. There is always the logical alternative of construing the cases to require the concurrence of the several factors stated in them. The generalization in terms of virtual monopoly is, therefore, inadequate, even as applied to the limited field of businesses affected with a public interest, for, apart from Brass $v$. North Dakota, it ignores the emphasis on the character of the commodity or service as a factor in the decisions. It is even more incorrect as applied to the whole field of price control. It is not relied on in either the cases involving price fixing during the war ${ }^{31}$ or those involving fixing the fees of attorneys in various situations..$^{22}$

An early attempt was made to limit the field of price control to businesses having some special relation to the possibility of op-

\footnotetext{
s9 Wyman, op. cit., supia note 7; also Wyman, Stato Control of Public Utilities (1911) 24 HARV. L. REV. 624.

${ }^{90}$ (1894) 153 U. S. 391, 14 Sup. Ct. 857.

91 United States v. Pennsylvania Cent. Coal Co., supra note 21; see also cases cited in note 24 .

92 See cases cited in notes 45,46 , and 87 .
} 
pression..$^{93}$ The expression, "special relation to the possibility of oppression", probably means only that that possibility must exist. The indefiniteness of the test is somewhat removed by specifying those facts which would usually establish that possibility. These include de jure or de facto monopoly or the grant of special privileges; the fact that the commodity is a necessary of life or an essential to the community's industrial welfare; or that it is one that has been immemorially subject to regulation. Their statement in the alternative is clearly incorrect. The theory would justify fixing the price of necessaries solely because they were such; but the decisions scarcely warrant so broad a proposition. Its inadequacy, in so far as it invokes virtual monopoly, requires no further consideration. This general test has recently been revived with some modification of the specific factors on which its applicability is made to depend..$^{04}$ The factors suggested as essential are that the industry must involve a necessity of life or at least a product of great importance to the welfare of the community, and the inadequacy of competition to protect the consumer. Their statement in the conjunctive represents a more accurate generalization than the earlier attempt. Neither, however, accords with the decisions sustaining price fixing for commodities or services which the public commonly uses ${ }^{05}$ unless that be given the rather forced construction of an equivalent for necessaries or products of great importance to the welfare of the community. It is the merit of these generalizations to have directed attention to the importance of oppression, or its possibility, as factors validating price control. The second element in the more recent of them will be considered in the discussion immediately following.

There has recently appeared a tendency to substitute for the conception of virtual monopoly that of the inadequacy of competition to protect the public. ${ }^{96}$ This theory makes such inadequacy the sole basis for including a business within the field subject to price control, and the adequacy of competition the decisive factor of exclusion from that field. The significance of this shift depends on the meaning of this later form of statement. It must clearly be taken to denote some condition other than the total absence of competition, since otherwise it would be merely another way of describing the fact of virtual monopoly in its most extreme form. The legal conception of virtual monopoly has included not only cases of complete monopoly but also those in which existing competition has been an ineffective check upon the economic

${ }^{93}$ Freund, op. cit., supra note 1, at 389.

${ }^{94}$ NOTE AND COMMENT (1920) 19 Mrch. L. Rev. 74.

${ }_{95}$ People v. Weller, supra note 16; In re Opinion of the Justices, supra note 16.

96 Simpson, Due Process and Coal Price Regulation (1924) 9 IowA L. BuLL. 145. See for an early intimation in that direction Lewis, Can Prices be Regulated by Law? (1893) 32 AM. L. REG. 9. 
powers of one or a limited number of the producing units. There would, therefore, be no particular value in supplanting virtual monopoly with the inadequacy of competition if the latter meant no more than the absence of a sufficient degree of competition to make it effective. There are, however, situations in which, although there exists bona fide competition among those who supply the commodity or service, that group as a whole has an advantage over the consuming group as a whole. This usually means no more than that the intensity of the competition among consumers for an article, of which there is but a limited quantity available as compared with the total demand therefor at all prices, permits the owners of the supply to realize a price deemed unfair by reference to some assumed standard of a fair price. The rent cases involved situations of that type. Although the court described them as monopolies, ${ }^{17}$ it is clear that they were monopolies of a different character than that involved in the Mumn case, in which the elevator owners had fixed a uniform price seale by agreement. It is unfortunate to use the same term to describe both the situation in which there is no competition or practically none, and that in which the keenest competition may exist but be ineffective because of intense competition among consumers to protect them from extortion. The latter is more correctly described as one in which existing competition is inadequate to afford the public that protection against extortionate prices which competition is assumed to give. The conception is broad enough to include not only every case of virtual monopoly, but also those in which the failure of the protective function of competition is due to other conditions affecting supply, and to conditions of demand. It is, therefore, something more than a mere substitute for virtual monopoly ; it states a more inclusive theory that in a sense includes the factor of the character of the commodity or service being regulated. This wider implication has not always, if ever, been clearly grasped.9s It is, however, a more adequate formulation even of those factors of supply relied on in adjudging the validity of price control than is that in terms of virtual monopoly. It is in its wider sense above indicated the nearest approach to an adequate generalization of the field of price control. It suffers from the defect common to all the generalizations thus far considered in that it takes no account of those instances in which price control is used as a method for preserving competition rather than as a means for protecting the public against the results of its inadequacy. The cases requiring the maintenance of a fixed relation between prices of the same commodity in different markets are of that type. It seems to have been tacitly as-

${ }^{97}$ Block v. Hirsh, supra note 18.

${ }^{98}$ See supra note 94 . 
sumed that these cases can be ignored in discussing the problem of price control.

The adequacy of these various attempted generalizations was tested primarily with reference to the reasoning of the cases. The conclusions will require no modification if that is supplemented by their facts. There was no virtual monopoly in either Brass $v$. North Dakota, the cases of price fixing during the war, those involving the fixing of attorney's fees, or those dealing with the establishment of a price standard in terms of prices voluntarily maintained in other markets. There is no proof that the threat to the public's interest as consumers was in every case due to the failure of the protective function of competition, unless it be assumed that society relies upon competition to prevent all socially undesirable results so that their very existence establishes its inadequacy. What the courts had in mind in the fee fixing cases was the inequality in the bargaining powers of the attorneys and their clients of a particular class; and the presence of that same fact furnished the basis for a part of the argument in the insurance cases. That is not a fact which competition (a word in its correct sense meaning only the rivalry among those on the same side of the market) could be expected to prevent or even remedy. It is rather a factor validly to be considered in deciding the extent to which society should rely upon competition. The ticket scalping cases show that price control has invaded a field not concerned with necessaries of life or products of great importance to the social welfare.

No theory as to the field within which price control is constitutional can ignore any of its forms. What is needed is a theory that shall comprehend them all, a broader principle than can be derived by considering only a limited section of the whole field. This is required in order to prevent the problem of price control from being solved in terms of technical considerations that will inevitably restrict its scope more than is demanded by the rather vague "due process" standard that constitutes the principal barrior to this form of social experimentation. The problem is to define that principle in terms which will not be so vague as to be practically useless and yet which will not sacrifice completeness to the desire for definiteness. Such a theory must first of all summarize the decisions to date, but should also, if possible, serve as the basis for predicting what particular instances, the legal status of which had not yet been determined, would probably be held to be within that field. It should function as any other scientific generalization except that the character of the data on which it is based will almost certainly reduce the probability of successful prediction. The ideal would be a principle that made the validity or invalidity of price fixing a corrollary of the existence or nonexistence of facts themselves capable of objective determination, 
whether immediate or through inferences that involved only judgments of what is as distinguished from judgments implying valuations. The principles thus far applied to the problem that most nearly approximate this standard are those stated in terms of monopoly, legal or virtual, of the grant of special privileges of franchises, and of the common use of the commodity by the public, rather than its necessary or indispensable nature. The requirement that the commodity be a necessary of life or a product of great importance to the community's welfare describes facts the existence of which can be determined only by first postulating some theory of ends. The statement that competition has not adequately protected the public is meaningless without some theory as to the kind of society that is wanted, by reference to which the quality of the results can be tested. A judgment that certain prices are oppressive or extortionate implies the existence of some standard of fair or just prices. All these tests, including those that appear to denote merely objective facts, postulate norms. The difference between the two types is not that the one has no reference to norms, but rather that it considers the particular norms that are assumed as beyond dispute. To limit the field of price control to cases in which there exists virtual monopoly is to assume that the "due process" clauses are a definite commitment to the theory that government cannot attempt to modify the economic results of competition. To define that field so as to include all cases in which the public is not adequately protected by competition, whether because of its partial or complete absence, the level of competitive standards, or any other reason, opens up the whole question of what kind of society is desired. It is possible thereunder to question the validity of the assumption accepted as final by the virtual monopoly theory. The results and reasoning of the cases cannot, therefore, be made to fit any theory that correlates price control with one or a group of facts which do not involve an evaluation process. They are compatible only with one that includes an assumed social ideal. $0^{90}$

It is a grave defect of such theories as that of virtual monopoly that they conceal the fact of such an assumption. This is not true of such a theory as that of the inadequacy of competition to protect the public. The latter theory, however, is too narrow in limiting price control to the correction of those evils which result from the imperfections of competition as a regulative force. There are evils incident to economic activity that cannot be ascribed to that cause unless that conception be taken to mean no more than

\footnotetext{
${ }^{39}$ The social ideal is described as assumed for the reason that, in the writer's opinion, there are not yet existent sufficient data to prove the necessary validity of any such ideal. The efforts of philosophy to establish such ideals have been valuable almost entirely as examinations of such assumptions.
} 
that a competitive régime is not a guarantee against the existence of all socially undesirable results. That is in substance equivalent to saying that the existence of those evils is the significant factor determining the validity of price control; and that might as well be stated directly. The results and reasoning of the decisions are compatible only with that view. Fee fixing is justified to prevent oppression and extortion irrespective of the causes producing them. Limiting sellers to prices defined by reference to those voluntarily maintained by them in other markets is sustained without any reference to the inadequacy of competition to protect the public, but rather to maintain competition which is assumed to be an adequate protective mechanism. It is the existence of evils that constitutes the real basis for permitting price control, not the fact that these result from particular causes. ${ }^{100}$ They will usually be due to causes operating in our economic price system; but there are many reasons why that might produce socially undesirable results. It functions in a social order in which economic power is very unequally distributed. The result may be that the community's economic powers are directed into channels deemed injurious, or at least less important than alternative channels. The federal government dealt with this problem during the war through an extensive system of rationing and priorities. The regulative function of price in our economic system suggests the possibility of employing price control for the same ends, even though it might be practically useless unless supplemented by some such system of control as existed during the war. The important thing, however, is that price control should not be limited to the correction of only those evils arising out of or in connection with the price system which competition has failed to prevent. The decisive factor should be, and is, not that competition has failed to protect tre public but that price control is a reasonable method for dealing with those evils. No harrower generalization adequately takes account of the results and reasoning of the cases defining the field of price control in all, as distinct from some only, of its forms.

The suggested theory, like that of the inadequacy of competition as a protective device, implies a standard for determining what constitute evils or socially undesirable results. The constitutional problem is such that this is inevitable, and it might as well be expressly recognized as tacitly assumed. A theory of price control that tests its validity by reference to a social ideal runs the risk of being so vague as to be practically worthless. The conception of a social ideal is too complex to be simply stated. The practical impossibility of giving full scope to the almost infinite individual claims of the members of a social group necessi-

\footnotetext{
100 This method of approach is adopted in American Coal Mining Co. v. Special Coal and Food.Comm. of Ind., supra note 17.
} 
tates selection. The construction of a social ideal involves an evaluation of these frequently competing claims. Attempts to arrange them in a scale of relative significances by reference to some single principle of evaluation have invariably proved futile. The formula of utilitarianism is neither better nor worse in this respect than those of the metaphysical jurists. The courts have wisely refrained from any such ambitious attempts. Their frequent emphasis on individualism has seldom, if ever, gone to that extent. They have followed the practice, not restricted to them, of constructing it piecemeal. It would be almost impossible to discover an inclusive standard invariably applied in passing on the validity of legislation; but it is possible within limits to trace the outlines of the standard applied in connection with particular problems. The social ideal postulated in dealing with price control has been one in which individual freedom in economic matters has in general been assigned a greater significance than equalizing economic opportunities or insuring that the basic wants of one individual should be provided for before lesser wants of another should be satisfied. It has assumed that competition is usually a more efficient regulative method than governmental interference to insure the socially desirable production and distribution, or at least that the limitation of freedom incident to the latter system generally more than counterbalances the gains therefrom in other respects. The theory of a just price may have disappeared from economic theory; but it has persisted in law to mitigate somewhat the logical results of incorporating in the social ideal the elements just discussed. The standard of the just price has usually, but not always, been one determined under free competition among the producers. These are the important elements of the standard used to test the validity of price control. The truth of the assumptions implicit in their selection has never been either proved or disproved; and it is doubtful whether it ever can be. The injection of ethical notions of fair price considerably enhances the probability of error in making predictions on the basis of that standard. This is increased by the fact that the courts have recognized that a dynamic conception of the ideal is not inconsistent with the constitution. The field of price control, therefore, cannot be said to have been accurately defined if the standard is limited to that thus far developed. The next decision may introduce a new element or change the relative emphasis on the old. This uncertainty can be reduced, but not entirely eliminated, by considering the nature of the court's function in dealing with this problem.

The selection of values and the determination of their relative order is a problem in social policy. It would normally be for the legislature to perform those functions in so far as the state might undertake to make a particular selection or order effective through law. The courts have frequently exercised them even 
in cases not involving constitutional issues. The conception of public policy has proved a most efficient tool in this connection. ${ }^{101}$ It is, however, in the field of constitutional law that the courts have done so most frequently, and particularly in developing the meaning of "due process" as a limit on the substance of legislation. The "due process" clauses circumscribe the field within which the legislature can exercise its policy-determining powers. They are themselves expressions of a policy, and designate, vaguely though it be, certain values deemed of such importance that the legislature has been inhibited from selecting others at their expense. It is idle to speculate whether that theory accords with the intention of their framers; it represents the law today. The courts' problem is to determine what those values are, and when the legislative selection of competing values sacrifices them unduly. The term "due process" itself suggests no specific content, and this makes it inevitable that the courts deal in problems of policy in giving it that content. The determination of when competing values infringe unduly upon those protected by the "due process" clauses is a question largely of policy. It is, therefore, idle to criticize the courts for invading the field of policy in deciding "due process" cases. There is nothing else that they can do as long as the doctrine prevails that these clauses limit the subject matter of legislation. This might as well be frankly recognized by all concerned. It is not the purpose to discuss generally the values protected by those clauses. Those thereby protected against undue infringement through price control have already been stated in so far as derivable from decisions to date. It remains to determine the principles that will probably govern their expansion or modification; and these can be developed only by considering the fundamental factors in the problem of price control.

The "due process" clauses give a measurable constitutional protection to individualism. Price control limits individual freedom in a field which will probably continue to be considered for an indefinite period a rather important sphere of individual activity. It has thus far generally aimed to keep prices down to a level deemed fair or just, and has seldom been consciously adopted as a device for modifying the ultimate distribution of economic products, or for giving direction to the community's economic powers. These are, however, the practically inevitable effects of price fixing. To fix prices involves something more than merely determining what buyers shall pay; it is equally significant in determining who shall buy. It prevents those of superior wealth from exclud-

101 Waite, Public Policy and Personal Opinion (1921) 19 Mrch. L. REV. 265; see also Waite, Judicial Statesmen (1922) 8 A. B. A. Jour. 375. For an extensive general discussion of the "due process" clause see Kales, "Due Process," the Inarticulate Major Premise and the Adamson Aot (1917) 26 Yale LaW Journal, 519. 
ing from the class of buyers those of lesser economic power by preventing the former from bidding up the price to the point where the latter cannot afford to buy. It is essentially as much a limit on the buyers as on the producers, although this aspect usually escapes attention because the buyers do not ordinarily complain of prices fixed below what they would be willing to pay. It is in connection with the rent cases that the effect of price fixing upon the distribution of the social product appears most clearly. Its character as a factor in determining the channels into which the community's economic powers shall be directed is expressly recognized in defining the rate of return that must be allowed if rates are not to be held confiscatory. The really significant social fact about prices is that they are factors in those distributive processes. The formulation of any rational theory of price control must take account of those relationships. The "due process" clauses do not protect that particular distribution of the social product and of the community's economic powers which results from permitting complete individual freedom in fixing prices. Every case sustaining price fixing negatives it, even though not justified on that basis. The rather common provisions as to certificates of convenience and necessity limit individual freedom in directing economic forces. It is not a constitutionally protected privilege of those able to afford it to waste a commodity, even when that entails the total sacrifice of more important wants. The functioning of unregulated prices may produce that very result. The values actually realized in a given society, and the order of importance assigned to them, are to some extent functions of these distributive processes, whether as causes or effects it is unnecessary to decide. It is only necessary to recognize that the price system is an important factor in creating a social order, and that the actual order that competitive individualism has produced shows many instances of overemphasizing some values and underestimating others. This statement assumes a social ideal and would involve circular reasoning if the purpose were completely to define that standard. That, however, is not the aim of the present discussion; its chief purpose is to maintain the thesis that, given the admittedly dynamic character of the soeial ideal, the modifications of that now assumed by the courts in dealing with price control can and should be determined only by recognizing the social function and results of the price system. The adoption of that approach should make it clear that there are values that the state may protect through price fixing other than those concerned in maintaining a fair relation between prices and costs. There is no logical reason to prevent its use to equalize the opportunities for acquiring necessities by preventing the economically strong from bidding the economically weak out of the market, or to secure a more effective utilization of natural 
resources and economic power. The probability that such uses of price fixing will be sustained will be enhanced if the traditional approach to the problem is abandoned in favor of the more rational one here contended for.

The field within which price control is valid can never be dofined with the exactness which characterizes a mathematicu. formula. The problem is, in a sense, insoluble; but it should at least be stated so as not to conceal its real character. Its adequato consideration requires a grasp of the nature of the judgment that courts make in deciding questions of that character. It is only by stressing the fact that they are determining the scale of values that society may make effective through law that its consideration can be freed from the deadening effects of such phrases as "affected with a public interest" or "social justice". Courts cannot, in defining the field of price control, escape the necessity of formulating some theory as to the desirable distribution of wealth and economic powers. They cannot do that without constructing a scale of values by reference to which they can adjudge the desirability or undesirability of given results. They do this whether they sustain or deny the validity of price fixing. The conscious recognition of this process is the sine qua non to the consideration of the problem in terms of the realities involved, and to the discovery of the lines of analysis that will have to be followed unless it is to continue enmeshed in the tangles of meaningless generalities. 